\title{
33. CHANGES IN BENTHIC FORAMINIFER ASSEMBLAGES ACROSS THE HOLOCENE/PLEISTOCENE BOUNDARY, SITES 619, 620, 621, 622, AND 624, DEEP SEA DRILLING PROJECT LEG 96 ${ }^{1}$
}

\author{
C. J. Schroeder, Dalhousie University ${ }^{2}$
}

\begin{abstract}
On Leg 96 of the Deep Sea Drilling Project, holes were drilled on the lower and middle Mississippi Fan (nine sites) and in the Pigmy and Orca basins (one site each) in the Gulf of Mexico. The Holocene/Pleistocene boundary was defined by typical planktonic foraminifers. Mississippi Fan sites contain a short Holocene sequence compared with the Pigmy Basin sequence. Benthic foraminifers from the upper core sections at five selected sites were studied. The diverse Holocene assemblage on the surface of the fan is dominated by Cibicidoides wuellerstorfi, Hoeglundina elegans, and Globobulimina spp. Below $20 \mathrm{~cm}$ sub-bottom, this assemblage is replaced by typical outer shelf and upper slope species indicating downslope transport of shelf sediments onto the fan. This transition is represented by a lithologic change from a foraminiferal ooze above to a clay-mud facies below. In Pigmy Basin, the top $5 \mathrm{~m}$ represent a diverse foraminiferal assemblage. The dominant species (i.e., Osangularia culter, Eponides turgidus, $H$. elegans, $C$. wuellerstorfi, Brizalina, spp., and Epistominella exigua) fluctuate throughout the Holocene and decrease drastically below the Holocene/ Pleistocene boundary.
\end{abstract}

\section{INTRODUCTION}

During Deep Sea Drilling Project (DSDP) Leg 96 a series of nine sites in the lower and middle Mississippi Fan and one site each in the Pigmy and Orca basins were visited. The cored material from the holes drilled at those sites provided the opportunity to study the response of benthic foraminifers to an environment with extremely high sedimentation rates. This chapter documents the changes of benthic foraminiferal assemblages across the Holocene/Pleistocene boundary, based on dense sampling in the upper interval of each site.

The biostratigraphic zonation used in this study is that of Ericson and Wollin (1968) (see Explanatory Notes, this volume). The Holocene (Ericson Zone $\mathrm{Z}$ ) is defined by common to abundant occurrences of Globorotalia menardii. The upper sequence of the late Wisconsin glacial (Ericson Zone Y) is characterized in the studied area by a transitional interval, indicated by the absence of the warm water indicator $G$. menardii and the cool water indicator $G$. inflata. This study covers only Zone Z and the upper portion of Zone Y.

Only five holes from the nine sites on the Mississippi Fan supplied sufficiently closely spaced samples for this study. The upper section of Holes 624 and 624A (3198 $\mathrm{m}$ water depth), located on the lower fan, and Holes 620 $(2612 \mathrm{~m}), 621(2485 \mathrm{~m})$, and $622 \mathrm{~A}(2495 \mathrm{~m})$ on the middle fan (Fig. 1) were examined for their foraminiferal content. The thin Holocene interval (Zone Z) in the fan varies in thickness from $25 \mathrm{~cm}$ on the lower fan to 1.50 $\mathrm{m}$ on the middle fan. This zone is defined at the top by a planktonic ooze which changes downhole (below 10 to

\footnotetext{
I Bouma, A. H., Coleman, J. M., Meyer, A. W., et al., Init. Repts. DSDP, 96: Washington (U.S. Govt. Printing Office).

2 Address: Department of Geology, Dalhousie University, Halifax, Nova Scotia B3H 3J5, Canada.
}

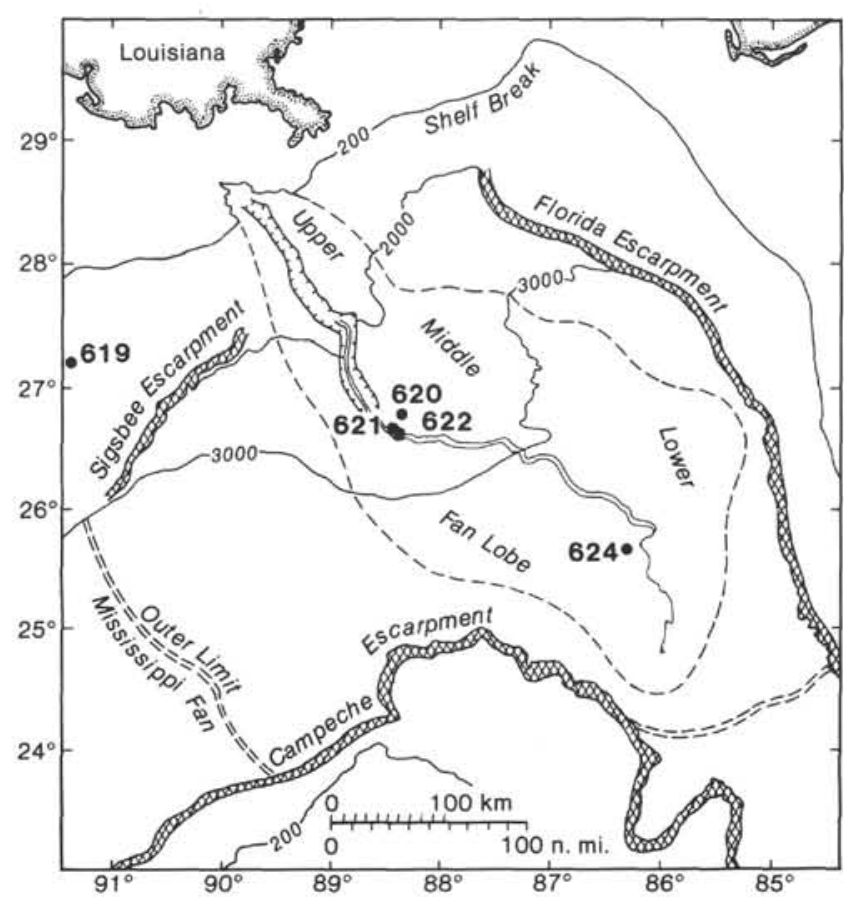

Figure 1. Location map of Sites $619,620,621,622$, and 624 , DSDP Leg 96.

$20 \mathrm{~cm}$ ) to an olive gray mud with abundant silt layers. The lithologic change is not coincident with the Holocene/Pleistocene boundary.

Site 619 is located in Pigmy Basin (2274 m water depth), an intraslope basin off Louisiana (introductory chapter and Site 619 chapter, this volume). A nearly complete Wisconsin biostratigraphic sequence that includes Ericson Zones Z, Y, and X was recovered. For further biostratigraphic results of the foraminifers in Pigmy Basin, see Kohl (this volume). The Holocene is rep- 
resented by the upper $5 \mathrm{~m}$ of sediment. The top of Zone $\mathrm{Z}$ is characterized by a planktonic ooze changing a few centimeters downcore into a mud facies with rare silt layers. This is similar to the relationship seen in the Mississippi Fan sites.

The faunal study of Site 619 allowed determinations of foraminiferal fluctuations in a mainly pelagic and hemipelagic environment. This was compared to the terrigenous depositional sequences at the fan sites, where the sedimentation is mainly influenced by erosional and aggradational events related to eustatic changes.

\section{METHODS}

A detailed documentation of the faunal changes across the Holocene/Pleistocene boundary required dense sampling intervals (1 to $10 \mathrm{~cm}$ ) in the upper few meters of the cores. Sample size was therefore limited at some sites to 3 to $10 \mathrm{~cm}^{3}$, which did not always provide sufficient individuals (100 specimens or more) for calculating meaningful percentage occurrences. In such cases (especially in the fan sites) the total number of the dominant species per $10 \mathrm{~cm}^{3}$ was chosen to illustrate the data. At Sites 619,622 , and 624 , additional mudline cores were taken (Holes 619A, 622A, and 624A) to recover enough material for this study.

The top sample of each core was stained with Rose Bengal on board ship to distinguish the live and dead components.

Each sample was washed with a fine water spray through a $63-\mu \mathrm{m}$ sieve, the residue dried at $50^{\circ} \mathrm{C}$, and examined for its benthic foraminifer content. Large samples (mainly in the top ooze) were split with a microsplitter and, whenever possible, 300 specimens were identified and counted. Most of the samples, however, contained less than 100 specimens. The benthic foraminifers were identified mainly on the species level.

\section{FAUNAL CHANGES}

\section{Pigmy Basin}

The changes in occurrence and abundance of benthic foraminifers within the Holocene can be studied in detail only in Hole 619A, located in Pigmy Basin. In this intraslope basin, the Holocene (Zone $\mathrm{Z}$ ) is represented by the upper $5 \mathrm{~m}$ of sediment (Fig. 2) and contains one short segment (Sample 619A-1-1, 70-90 cm) where the total benthic fauna decreases almost to zero, probably indicating a high dilution of the faunal content caused by rapid influx of hemipelagic mud sedimentation (see Kohl, this volume).

The dominant benthic species in Hole 619A are Osangularia culter, Eponides turgidus, Epistominella exigua, and Hoeglundina elegans, occurring in similar abundances. The surface sample contains a total of 80 benthic species, of which 31 are agglutinated taxa. The agglutinated faunal component diminishes downhole. The sediment also changes from a planktonic ooze to olive gray mud and the total benthic foraminifer fauna decreases markedly in total number $/ 10 \mathrm{~cm}^{3}$.

All dominant taxa fluctuate in abundance through the Holocene. Uvigerina spp. have their maximum occurrence in the lower part of the Holocene. Osangularia culter, an important component of the surface assemblage, decreases in this same interval (Fig. 2).

The Holocene/Pleistocene boundary is marked by a dramatic downhole decrease in foraminiferal content. This event was corroborated by studying the corresponding section in Hole 619, where samples in the interval be- tween 5 and $7.67 \mathrm{~m}$ sub-bottom are markedly impoverished in foraminifers.

\section{Mississippi Fan}

The selected sites in the middle fan (Holes 620, 621, and $622 \mathrm{~A}$ ) show changes in the benthic faunal content (Fig. 3) that are distinctly different from the changes observed at Pigmy Basin. The surface benthic assemblage is dominated by $C$. wuellerstorfi, H. elegans, Globobulimina spp., Uvigerina spp., and Oridorsalis umbonatus. Species diversity is relatively high, with over 40 taxa per sample. The percentages of the dominant taxa decrease below 10 to $20 \mathrm{~cm}$ sub-bottom at most sites and $C$. wuellerstorfi and $H$. elegans disappear completely downcore below $1 \mathrm{~m}$ sub-bottom. The $>63-\mu \mathrm{m}$ residue becomes very small downhole and there is a corresponding decrease in the diversity of benthic species. Species related to Brizalina, Fursenkoina, and, in the case of Holes 621 and $622 \mathrm{~A}$, Nonionella occur frequently in relatively high numbers. This transition in the foraminiferal content occurs above the Holocene/Pleistocene boundary. The change is apparently controlled by the diachronous sedimentological transition from a muddy foraminiferal ooze at the top of the cores to a clay and mud facies below.

Lower fan benthic foraminifers were studied in the uppermost sections of Holes 624 and 624A (Fig. 4). Only Hole 624 contains a muddy foraminiferal ooze at the top. The number of benthic species in this ooze is relatively low and the benthic fauna is dominated by $C$. wuellerstorfi accompanied by Globobulimina spp., Pyrgo murrhina, O. umbonatus, and a large number of agglutinated species. This particular layer was not recovered in Hole 624A, where the Holocene is only represented by the upper $25 \mathrm{~cm}$ of sediment. Below $25 \mathrm{~cm}$ sub-bottom, the residue $>63 \mu \mathrm{m}$ decreases significantly and the number of species drops to less than five species per sample. The dominant taxa are Praeglobobulimina $s p$., Valvulineria mexicana, and Rutherfordoides tenuis. Cibicidoides wuellerstor $f i$ is very sparse downcore in Ericson Zone Y.

\section{ECOLOGICAL IMPLICATION}

The actual sediment surface is missing from the top samples of the uppermost core at each site, as indicated by the absence of living specimens. This prevents a detailed ecological interpretation of the living assemblages. There is, however, a distinct difference in the fossil Holocene assemblages of benthic foraminifers from the intraslope basin versus those from the Mississippi Fan. Poag $(1981$, in press) characterized the Gulf of Mexico as having various predominant foraminiferal facies. According to these facies boundaries, the Pigmy Basin site would fall within the region typified by the dominant genera Bulimina and Brizalina and not far from the predominant facies of Eponides and Nuttallides. Accordingly, at Site 619, Brizalina, Bulimina, and Eponides, together with Osangularia, dominate throughout the Holocene.

The Mississippi Fan and Sigsbee Plain are characterized, according to Poag (1981), by the Cibicides predom- 


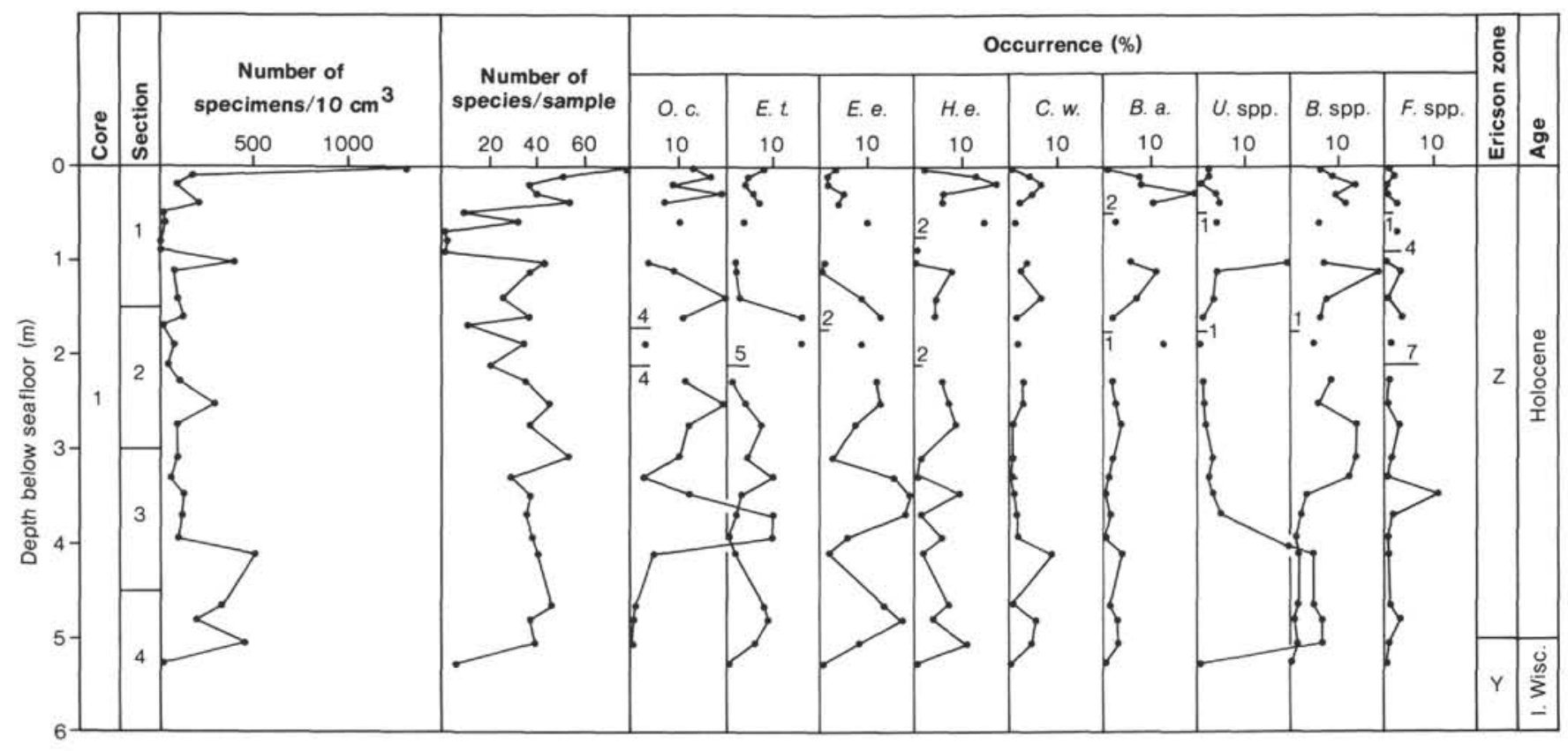

Figure 2. Percentage occurrences of selected benthic species during the late Quaternary in Pigmy Basin, Hole 619A. The horizontal bars indicate intervals with a sparse faunal content and the number indicates the total number per $10 \mathrm{~cm}^{3}$. Abbreviations for Figures $2,3,4$ are as follows: B. spp. = Brizalina spp., B.a. = Bulimina aculeata, $C . w .=$ Cibicidoides wuellerstorfi, E.e. $=$ Epistominella exigua, E.t. $=$ Eponides turgidus, $F$ spp. = Fursenkoina spp., G. spp. = Globobulimina spp., H.e. $=$ Hoeglundina elegans, N.a. $=$ Nonionella atlantica, O.c. $=$ Osangularia culter, $O . u .=$ Oridorsalis umbonatus, $P$. sp. $=$ Praeglobobulimina sp., R.t. $=$ Rutherfordoides tenuis, $U . \mathrm{spp} .=$ Uvigerina spp., V.m. $=$ Valvulineria mexicana.

inant facies, represented mainly by Cibicides wuellerstorfi (Cibicidoides in this study). The Holocene assemblage recovered at the fan sites confirms this pattern, with $C$. wuellerstorfi being the most abundant species, accompanied by Hoeglundina elegans and Globobulimina sp.

Culver and Buzas (1981a, b, 1983) defined four foraminiferal zoogeographic provinces. The slope and abyssal plain are contained in one province characterized by C. wuellerstorfi, $O$. culter, Laticarinina pauperata, Cibicidoides robertsonianus, and Gyroidina orbicularis as diagnostic species. These species occur in the studied surface samples of all sites. For the outer shelf province, Culver and Buzas established as characteristic taxa several species of the genera Brizalina, Bolivina, and Fursenkoina. The relatively high numbers of these taxa in Holes 621 and $622 \mathrm{~A}$, below the foraminifer-rich zone, support the interpretation of downslope transportation of significant amounts of outer shelf material to the middle fan. This is also supported by the consistent occurrence of typical neritic species like Ammonia beccarii and Hanzawaia concentrica (see Kohl et al., 1985).

Poag (1981) reported that Brizalina and Uvigerina are associated with the oxygen-minimum layer which occurs in water depths between 300 and $900 \mathrm{~m}$ in the Recent Gulf of Mexico.

\section{CONCLUSIONS}

In the Gulf of Mexico, the Holocene/Pleistocene boundary can be determined by the dominance of either Globorotalia menardii above or $G$. inflata below. The late Wisconsin glacial, for the sites studied, is characterized by a transitional zone with the absence of both planktonic species.
In the Mississippi Fan, this boundary is not reflected by a distinct change in the benthic foraminifer assemblage. Bathyal benthic species like Cibicidoides wuellerstorfi, Hoeglundina elegans, and Globobulimina spp. dominate the surface assemblage. They decrease coincidentally downhole with a lithological change from a planktonic foraminiferal ooze at the top of Ericson Zone $\mathrm{Z}$ to clay-mud facies below. Outer shelf and slope species of Brizalina and Fursenkoina dominate the fauna in the clay-mud facies (Fig. 5). This change above the Holocene/Pleistocene boundary indicates an increase in sedimentation rates on the fan through abundant downslope transportation of terrigenous material in the early Holocene.

In Pigmy Basin, a diverse Holocene assemblage comprises the upper $5 \mathrm{~m}$ of sediment and is characterized by distinct changes in the abundance of all dominant species (Fig. 2). Because Site 619 is in a blocked canyon, the glacial and Holocene sediments are of hemipelagic origin rather than from debris flows as observed at the fan sites.

Based upon the upcore increase in abundance of warmwater planktonic foraminifers and the increase in diversity of the benthic fauna during the Holocene (Zone Z), it appears that there is an increased warming trend coincident with the rise in sea level. The rise in sea level caused a reduction in sedimentation from the Holocene/ Pleistocene boundary to present day.

\section{TAXONOMIC NOTES ON SELECTED AGGLUTINATED SPECIES}

Taxa of agglutinated foraminifers from the deep-water regions of the Gulf of Mexico are not as well docu- 


\section{J. SCHROEDER}
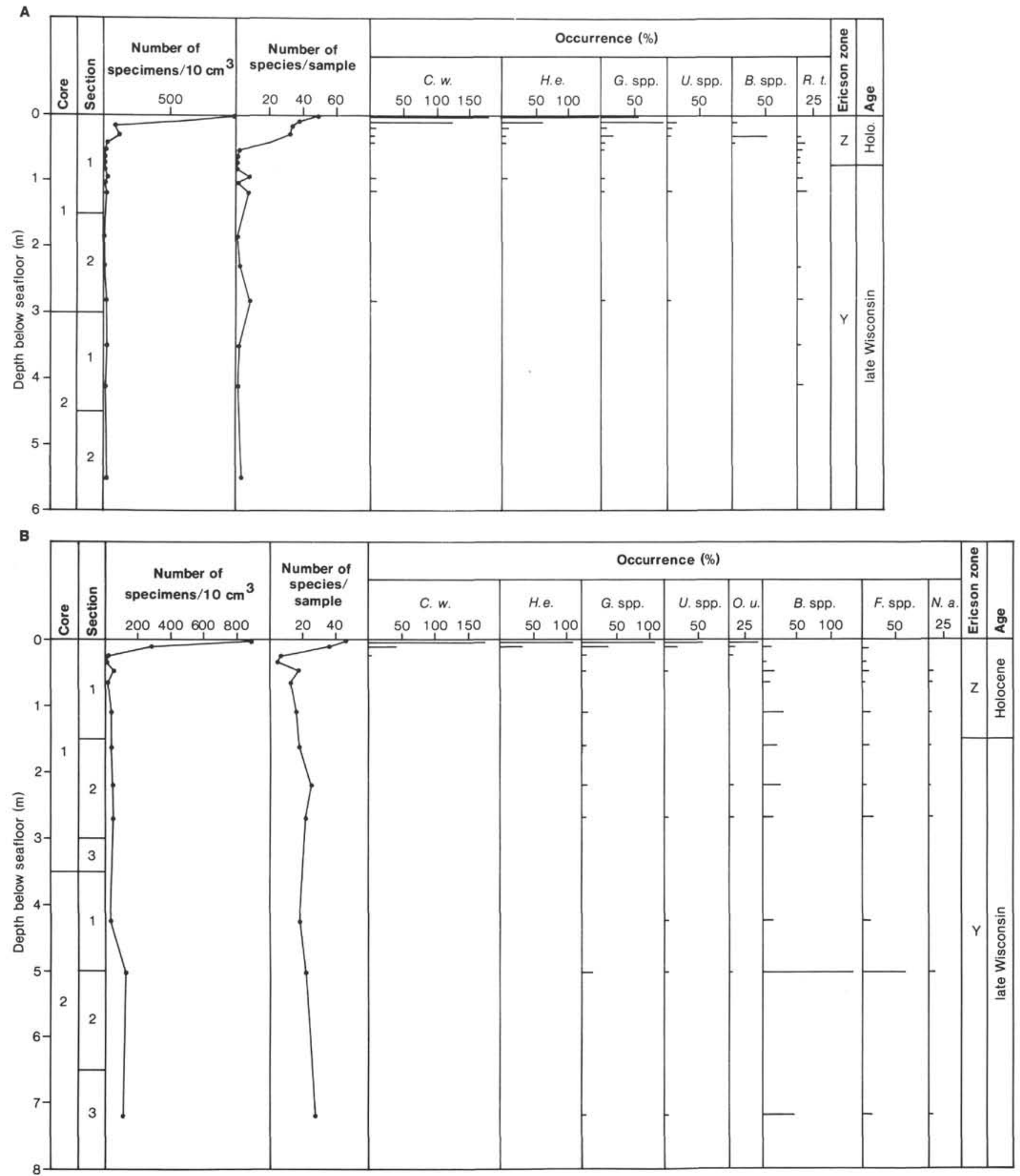

Figure 3. The total number of selected benthic species $/ 10 \mathrm{~cm}^{3}$ of the late Quaternary in middle fan sediments. (A) Hole 620. (B) Hole 621: (C) Hole 622A. For abbreviations, see Figure 2. 


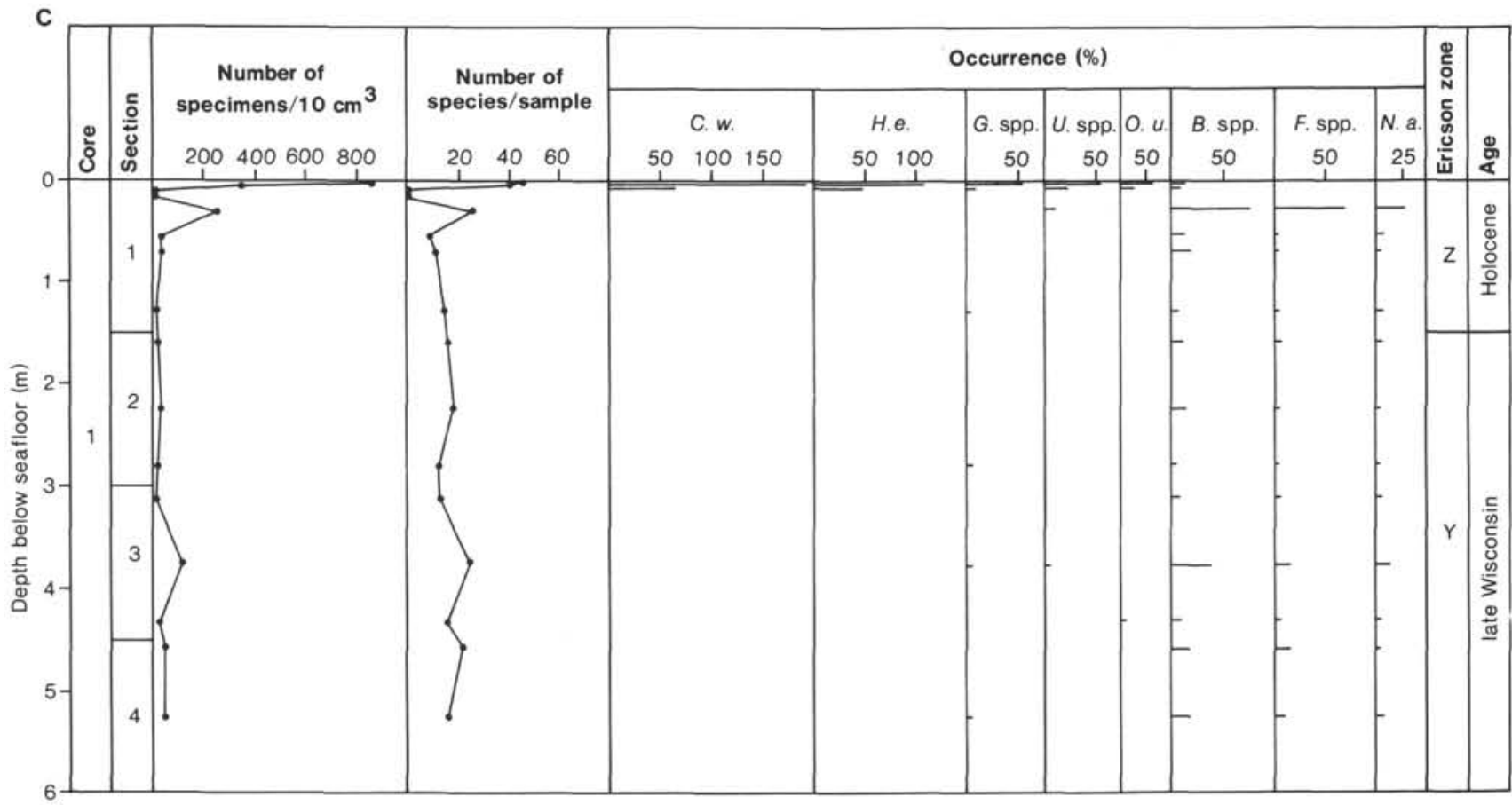

Figure 3 (continued).

mented in the literature as the calcareous species. Some illustrated work on this group has been completed by Phleger and Parker (1951), Parker (1954), LeRoy and Hodgkinson (1975), and Poag (1981). Observations on 42 taxa are added to the knowledge of this interesting group.

All specimens discussed come from surface samples at the various sites visited on Leg 96. Many of the species have an iron-rich cement and are abundant only in the surficial oxidized sediment layer. A few bleached specimens were found in deeper layers in a very fragile state of preservation. Loss of wall stability is greatly influenced by reduction of the stabilizing iron (Sidner and McKee, 1976).

No Rose Bengal-stained specimens were found and, based on that observation, it is assumed that at least the upper 1 to $2 \mathrm{~cm}$ layer was lost during the coring process. The selected sites do not reflect a wide depth range. Therefore, the material is not suitable for studying the bathymetric trends of the various agglutinated species.

The classifications and the concept of genera adopted in this study follow that of Loeblich and Tappan (1964), unless otherwise noted.

\section{ASTRORHIZIDAE Brady, 1881}

Hyperammina elongata Brady

(Plate 1, Fig. 5)

Hyperammina elongata Brady, 1878, p. 433, pl. 20, figs. 2a, b; Barker, 1960 , pl. 23 , fig. 8 .

Remarks. Test with a smooth, fine grained wall structure.

\section{Hyperammina laevigata Wright} (Plate 1, Fig. 6)

Hyperammina elongata Brady, var. laevigata Wright, 1891, p. 466, pl. 20, fig. 1.

Hyperammina laevigata LeRoy and Hodgkinson, 1975, pl. 1, fig. 9.
Remarks. Test with a very smooth surface in comparison to $H$. elongata, grains are almost not visible, elongated proloculus.

\section{Hyperammina sp.}

(Plate 1, Fig. 4)

Remarks. Test agglutinates coarse mineral grains.

\section{Rhabdammina abyssorum Carpenter (Plate 1, Fig. 1)}

Rhabdammina abyssorum Carpenter, 1869, p. 60; Barker, 1960, pl. 21, figs. $1-8,10-13$.

Remarks. In order to recognize this species, the central chamber with radiating tubular arms must be preserved.

\section{Rhabdammina discreta Brady}

(Plate 1, Fig. 2)

Rhabdammina discreta Brady, 1881, p. 48; Barker, 1960, pl. 22, figs. 7-10.

Remarks. Annular constrictions are the typical feature.

\section{Rhabdammina linearis Brady}

(Plate 1, Fig. 3)

Rhabdammina linearis Brady, 1879, p. 37, pl. 3, figs. 10, 11; Barker, 1960, pl. 22, figs. 1-6.

Remarks. Test with a swollen central chamber.

\section{Rhizammina algaeformis Brady}

$$
\text { (Plate 1, Fig. 10) }
$$

Rhizammina algaeformis Brady, 1879, p. 39, pl. 4, figs. 16, 17; Barker, 1960 , pl. 28 , figs. 1-11.

Remarks. A branching, fragile test, with variable agglutinated material.

\section{Rhizammina indivisa Brady}

(Plate 1, Fig. 9)

Rhizammina indivisa Brady, 1884 , p. 227 , pl. 29, figs. 5-7; Barker, 1960, pl. 29, figs. 5-7.

Remarks. A nonbranching test that agglutinates mud and foraminiferal tests. 

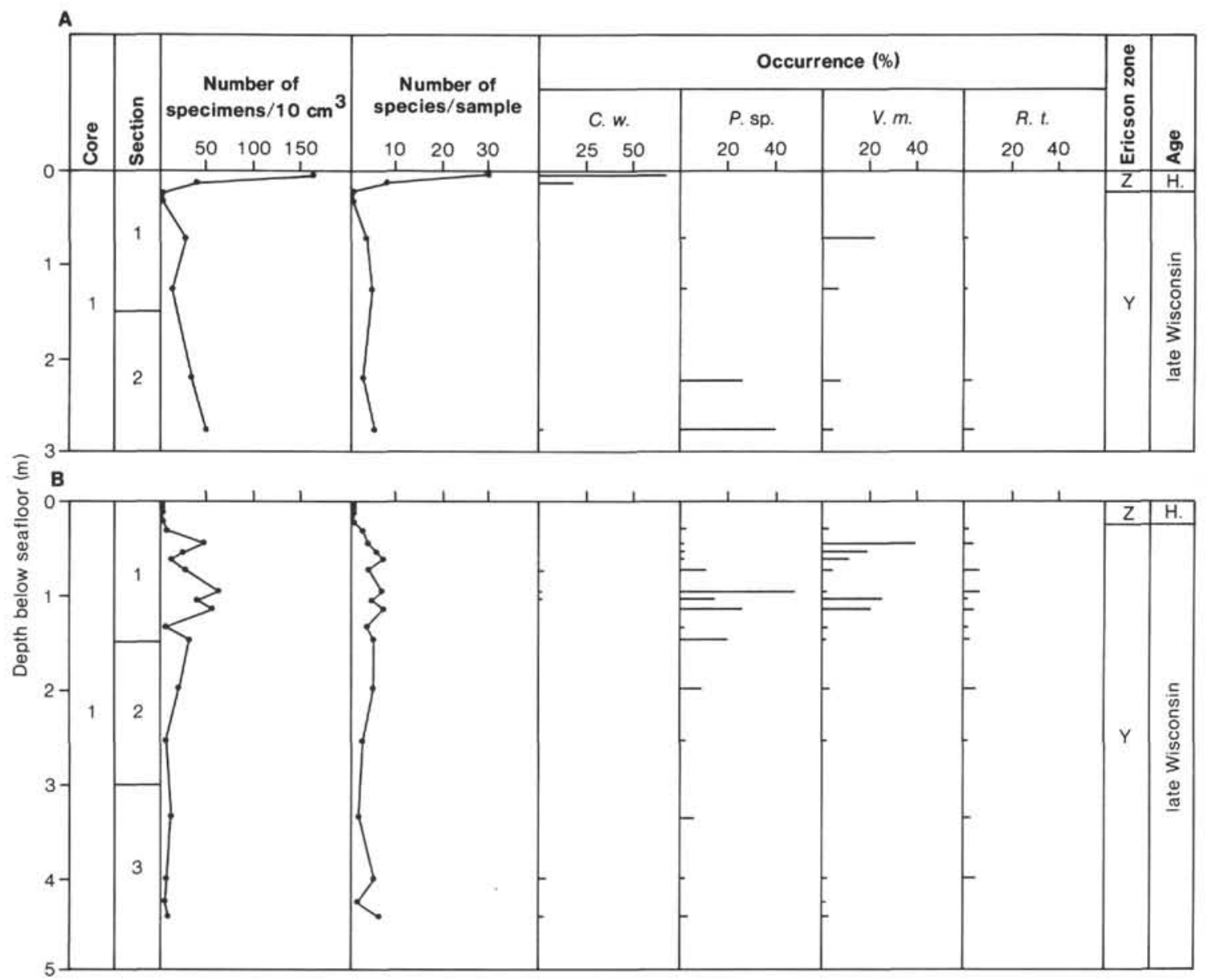

Figure 4. The total number of selected benthic species $/ 10 \mathrm{~cm}^{3}$ of late Quaternary sediments in lower fan Site 624. (A) Hole 624. (B) Hole 624A. For abbreviations, see Figure 2.

\section{Saccorhiza ramosa (Brady)}

(Plate 1, Fig. 8)

Hyperammina ramosa Brady, 1879, p. 33, pl. 3, figs. 14, 15.

Saccorhiza ramosa Barker, 1960, pl. 23, figs. 15-19.

Remarks. Test with a subglobular proloculus and irregularly branched that often incorporates sponge spicules in the wall.

\section{SACCAMMINIDAE Brady, 1884 \\ Technitella legumen Norman \\ (Plate 1, Fig. 7)}

Technitella legumen Norman, 1878, p. 279, pl. 16, figs. 3-4; Barker, 1960 , pl. 25 , figs. 8-12.

Remarks. Test agglutinates almost exclusively sponge spicules.

\section{Psammosphaera fusca Schulze}

(Plate 2, Figs. 3a, b)

Psammosphaera fusca Schulze, 1875, p. 113, pl. 2, figs. 8a-f; Milam and Anderson, 1981, pl. 1, fig. 6.

Psammosphaera fusca var. testacea Flint, 1899, pl. 8, fig. 2.

Remarks. This species occurs with large mineral grains or with foraminiferal tests agglutinated in the shell. Forms with mixed components were found as well; therefore, both end members are considered as belonging to the same species.

\section{Thurammina papillata Brady}

(Plate 2, Fig. 4a, b)

Thurammina papillata Brady, 1879, p. 45, pl. 5, figs. 4-8; LeRoy and Hodgkinson, 1975, pl. 1, figs. 6, 8.

Remarks. A globular test, variable in grain size, with an aperture on each small mammillate protuberance.

\section{AMMODISCINAE Reuss, 1862 \\ Ammodiscus incertus (d'Orbigny) (Plate 2, Fig. 11)}

Operculina incerta d’Orbigny, 1839, p. 49, pl. 6, figs. 16-17. Ammodiscus incertus Barker, 1960, pl. 38, figs. 1-3.

Ammodiscoides turbinatus Cushman, 1909, pl. 33, figs. 1-6.

Remarks. Based on an involute center, this species was related by Cushman to Ammodiscoides turbinatus, a concept accepted by Loeblich and Tappan (1964). This feature is not always distinct, especially in juvenile tests. Therefore it is not regarded as sufficiently important to create a new genus.

\section{Ammolagena clavata (Jones and Parker)}

$$
\text { (Plate 2, Fig. 1) }
$$

Trochammina irregularis var. clavata Jones and Parker, 1860, p. 304. Ammolagena clavata LeRoy and Hodgkinson, 1975, pl. 2, figs. 5-7.

Remarks. Test mostly attached to other foraminiferal tests, wall very fine grained and with a smooth surface.

\section{Glomospira charoides (Jones and Parker) \\ (Plate 2, Fig. 5)}

Trochammina squamata charoides Jones and Parker, 1860, p. 304. Glomospira charoides Barker, 1960, pl. 38, figs. 10-16.

Remarks. Test with streptospiral coiling and smooth wall texture.

\section{Tolypammina vagans (Brady)}

(Plate 2, Fig. 2)

Hyperammina vagans Brady, 1879, p. 33, pl. 5, fig. 3 . Tolypammina vagans Barker, 1960, pl. 34, figs. 1-5. 


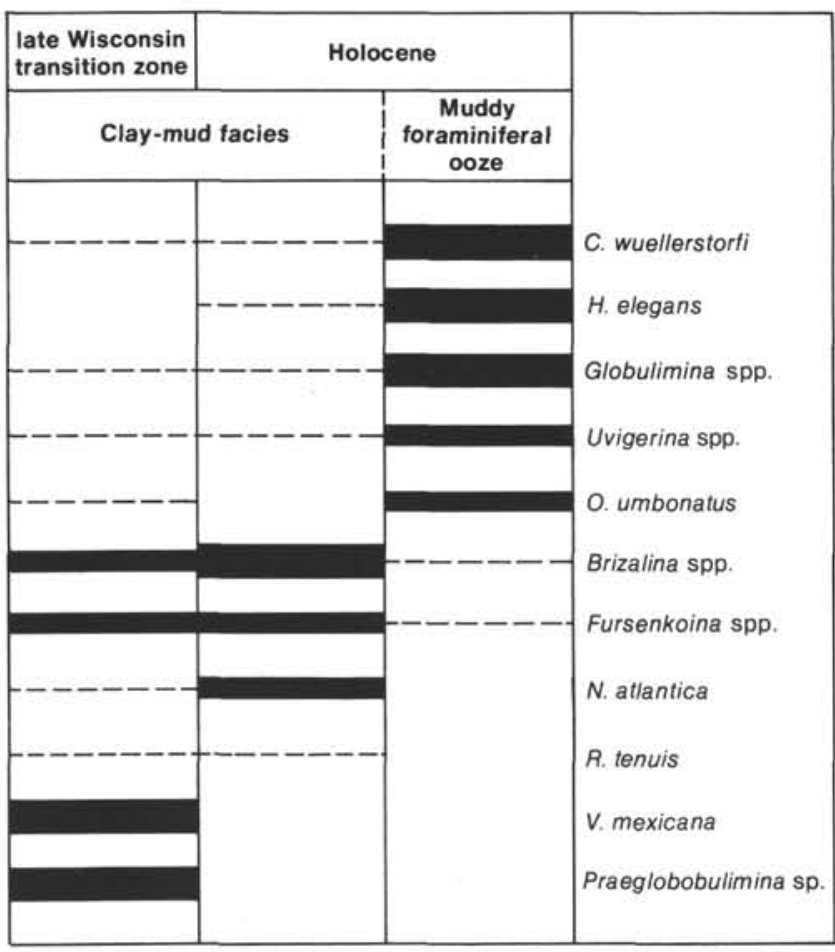

Abundant

Common ----Rare

Figure 5. Summary diagram of common benthic species in the Mississippi Fan [including data from Sites 620, 621, 622 (Hole 622A), and 624 (Holes 624 and 624A)], showing the abundance of dominant taxa in relationship to the Holocene/Pleistocene boundary. Note the dominance of $\boldsymbol{V}$. mexicana and Praeglobobulimina sp. below the boundary.

Remarks. Test often attached, wall coarser grained and more irregularly coiled than $A$. clavata.

\section{HORMOSINIDAE Haeckel, 1894}

Hormosina carpenteri Brady

(Plate 2, Fig. 9)

Hormosina carpenteri Brady, 1884, pl. 39, figs. 14-18; Barker, 1960, pl. 39, figs. 14-18.

Remarks. Large, relatively fine grained test, usually irregularly twisted.

\section{Reophax guttifer Brady}

(Plate 2, Fig. 8)

Reophax guttifer Brady, 1881, p. 49; Barker, 1960, pl. 4, figs. 7-9.

Remarks. Transitions between successively younger chambers are thin, the wall consisting of abundant sponge spicules, unusual for this species.

\section{Reophax pilulifer Brady \\ (Plate 2, Figs. 7a, b)}

Reophax pilulifer Brady, 1884, p. 292, pl. 30, figs. 18-20; Barker, 1960, pl. 30 , figs. 18-20.

Remarks. Very variable wall material. Fig. 7a shows a small, smooth test; fig. $7 \mathrm{~b}$ a very coarse grained test with agglutinated foraminiferal shells.

\section{Reophax distans Brady}

(Plate 2, Fig. 10)

Reophax distans Brady, 1881, p. 50; Barker, 1960, pl. 31, figs. 18-22.

Remarks. This species may occur with either oval or more globular chambers. The latter is described as $R$. distans delicatulus by Cush- man, 1920. Due to the fragility of the neck only single-chamber fragments were found in the studied material.

\section{LITUOLIDAE de Blainville, 1825 Adercotryma glomerata (Brady) \\ (Plate 3, Fig. 9)}

Lituola glomerata Brady, 1878, p. 433, pl. 20, fig. 1. Adercotryma glomerata Barker, 1960, pl. 34, figs. 15-18.

Remarks. The specimen figured is unusual in being coarse grained and spherical in shape.

\section{Ammobaculites agglutinans (d'Orbigny)}

(Plate 3, Fig. 15)

Spirolina agglutinans d'Orbigny, 1846, p. 137, pl. 7, figs. 10-12. Ammobaculites agglutinans Barker, 1960, pl. 32, figs. 19-21, 24-26.

Remarks. Initial chamber coiled, later portion rectilinear.

\section{Ammobaculites agglutinans var. filiformis Earland}

(Plate 3, Fig. 16)

Ammobaculites agglutinans var. filiformis Earland, 1934, p. 92, pl. 3,

figs. 11-13; Barker, 1960, pl. 32, figs. 22, 23.

Remarks. Test with a very smooth fine grained wall texture. The aperture has a short, wide neck. Size of chambers increases rapidly in coiled portion.

\section{Cribrostomoides nitidus (Goës)}

(Plate 3, Fig. 2)

Haplophragmium nitidum Goës, 1896, p. 30, pl. 3, figs. 8, 9. Cribrostomoides nitidus Poag, 1981, pl. 9, figs. 2, pl. 10, fig. 2a, b.

\section{Cribrostomoides subglobosus (Sars)}

(Plate 3, Fig. 5)

Lituola subglobosa Sars, 1872, p. 252.

Cribrostomoides subglobosus Milam and Anderson, 1981, pl. 3, fig. 1.

\section{Cyclammina pusilla Brady}

(Plate 3, Fig. 7)

Cyclammina pusilla Brady, 1881, p. 53; Herb, 1971, pl. 12, figs. 7a, b.

\section{Cyclammina trullissata (Brady)}

(Plate 3, Fig. 8)

Trochammina trullissata Brady, 1879, p. 56, pl. 5, figs. 10, 11. Haplophragmoides trullissata Cushman, 1920, pl. 9, fig. 5 .

Remarks. Test shows an inner alveolar structure, aperture equatorial interiomarginal.

\section{Haplophragmoides bradyi (Robertson)}

(Plate 3, Fig. 4)

Trochammina bradyi Robertson, 1891, p. 388.

Haplophragmoides bradyi Parker, F. L., 1954, pl. 1, fig. 16.

\section{Haplophragmoides canariensis (d’Orbigny)}

(Plate 3, Fig. 1)

Nonionina canariensis d'Orbigny, 1839, p. 128 , pl. 2, figs. 33,34 Haplophragmoides canariensis Barker, 1960, pl. 35, figs. 1-3, 5 .

\section{Haplophragmoides shaeriloculus Cushman \\ (Plate 3, Fig. 3)}

Haplophragmoides shaeriloculus Cushman, 1910, p. 107, test-fig. 165. Cribrostomoides shaeriloculus Echols, 1971, pl. 3, figs. 5-7.

Remarks. The holotype of this species shows five chambers, but specimens with four chambers have been designated as paratypes of this species as well.

\section{Recurvoides scitulus (Brady)}

(Plate 3, Fig. 6)

Haplophragmium scitulum Brady, 1881, p. 50.

Cribrostomoides scitulum LeRoy and Hodgkinson, 1975, pl. 4, figs. 5-6. 
Trochamminoides proteus (Karrer)

(Plate 2, Fig. 6)

Trochammina proteus Karrer, 1866, p. 494.

Trochamminoides proteus Barker, 1960, pl. 40, figs. 1-3.

Remarks. Coiling streptospiral to irregular, with a large umbilical aperture.

\section{TROCHAMMINIDAE Schwager, 1877}

Trochammina glabra Heron-Allen and Earland (Plate 3, Fig. 13)

Trochammina glabra Heron-Allen and Earland, 1932, p. 344, pl. 7 , figs. 26-28; Echols, 1971, pl. 10, fig. 1.

Remarks. Test usually has a fine grained smooth wall texture.

Trochammina globigeriniformis (Parker and Jones)

(Plate 3, Figs. 10a, b)

Lituola nautiloidea Lamarck var. globigeriniformis Parker and Jones, 1865 , p. 407 , pl. 15 , figs. $46,47$.

Trochammina globigeriniformis Barker, 1960, pl. 35, figs. 10, 11.

\section{Trochammina globulosa Cushman}

(Plate 3, Figs. 12a, b)

Trochammina globulosa Cushman, 1920, p. 77, pl. 16, figs. 3, 4; Parker, 1954, pl. 5, figs. 11, 12.

Remarks. Test with larger final chamber and a wider aperture than T. globigeriniformis.

\section{Trochammina rotaliniformis Heron-Allen and Earland}

(Plate 3, Figs. 14a, b)

Trochammina rotaliniformis Heron-Allen and Earland, 1911, p. 309; Cushman, 1920, pl. 16, figs. 1, 2.

\section{Trochammina soldanii Earland}

(Plate 3, Figs. 11a, b)

Trochammina soldanii Earland, 1936, p. 38, pl. 1, figs. 32-34.

Remarks. Coil of the spiral side not always distinct because of the coarseness of agglutinated material in the wall.

\section{ATAXOPHRAGMIIDAE Schwager, 1877 \\ Martinottiella occidentalis (Cushman) \\ (Plate 2, Fig. 15)}

Clavulina occidentalis Cushman, 1922, p. 87, pl. 17, figs. 1, 2.

Schenckiella occidentalis Phleger and Parker, 1951, pl. 2, figs. 5-7.

\section{Eggerella bradyi (Cushman)}

(Plate 2, Fig. 13)

Verneuilina bradyi Cushman, 1911, p. 54, text-figs. 87 a, b, pl. 6 , fig. 4 .

Eggerella bradyi LeRoy and Hodgkinson, 1975, pl. 6, fig. 4.

Remarks. Test with a small lip around the aperture, wall very fine grained and smooth.

\section{Eggerella propinqua (Brady) \\ (Plate 2, Fig. 14)}

Verneuilina propinqua Brady, 1884, p. 387, pl. 47, figs. 8-14. Eggerella propinqua Barker, 1960, pl. 47, figs. 8-12.

Remarks. Test with a coarser wall texture than E.bradyi. Attached forms are attributed by Cushman to E. affixa.

\section{Karreriella apicularis (Cushman)}

(Plate 2, Fig. 12)

Gaudryina apicularis Cushman, 1922, p. 72, pl. 8, fig. 4 .

Karreriella apicularis Barker, 1960, pl. 46, figs. 17-19.

Remarks. Test occurs elongate without a distinct increase in the size of chambers.

\author{
MILIOLIDAE Ehrenberg, 1839 \\ Sigmoilopsis schlumbergeri (Silvestri) \\ (Plate 2, Fig. 16)
}

Sigmoilina schlumbergeri Silvestri, 1904, p. 267, 269.

Sigmoilopsis schlumbergeri Barker, 1960, pl. 8, fig. 1.

\section{ACKNOWLEDGMENTS}

I thank the DSDP organization for the opportunity to participate on Leg 96. I would also like to thank Barry Kohl for many helpful discussions. David B. Scott, Franco S. Medioli, Felix Gradstein, and an anonymous reviewer kindly reviewed the manuscript. Bhan Deonarine prepared the scanning electron microscope photographs and Chloe Younger helped with the sample preparation.

\section{REFERENCES}

Barker, R. W., 1960. Taxonomic notes on the species figured by H. B. Brady. Soc. Econ. Paleontol. Mineral. Spec. Publ., 9:238.

Brady, H. B., 1878. On the reticularian and radiolarian Rhizopoda (Foraminifera and Polycystina) of the North Polar Expedition of 1875-76. Ann. Mag. Nat. Hist. (Ser. 5), 1:425-440.

, 1879. Notes on some of the reticularian Rhizopoda of the Challenger expedition. On new or little known arenaceous types. Q. J. Microsc. Sci., 19, Pt. 1:20-63.

1881. Notes on some of the reticularian Rhizopoda of the Challenger expedition. 1. Classification. 2. Further notes on new species. 3. Note on Biloculina mud. Q. J. Microsc. Sci., 21, Pt. 3: $31-71$.

1884. Report on the Foraminifera dredged by HMS Challenger, during the years 1873-76. Rept. Scientific Results Explor. Voyage HMS Challenger. Zoology, 9:1-814, pl. 1-115.

Carpenter, W. B., 1869. On the rhizopodal fauna of the deep-sea. Proc. Soc. London, 18(114):59-62.

Culver, S. J., and Buzas, M. A., 1981a. Distribution of recent benthic foraminifera in the Gulf of Mexico. Smithson. Contrib. Mar. Sci., 8:1-898.

1981b. Foraminifera: distribution provinces in the Gulf of Mexico. Nature, 290:116-117.

1983. Recent benthic foraminiferal provinces in the Gulf of Mexico. J. Foraminiferal Res., 13(1):21-31.

Cushman, J. A., 1909. Ammodiscoides, a new genus of arenaceous foraminifera. Proc. U.S. Natl. Mus., 36(1676):423-424, pl. 33.

1910. A monograph of the Foraminifera of the North Pacific Ocean. Bull. U.S. Natl. Mus., 71(1): 1-134. Astrorhizidae and Lituolidae.

1911. A monograph of the Foraminifera of the North Pacific Ocean. Textulariidae. Bull. U.S. Natl. Mus., 71(2):1-108. , 1920. The foraminifera of the Atlantic Ocean. Lituolidae. Bull. U.S. Natl. Mus., 104(2):1-111.

1922. The foraminifera of the Atlantic Ocean. Textulariidae. Bull. U. S. Natl. Mus., 104(3):1-143.

Earland, A., 1934. Foraminifera. Part III. The Falklands Sector of the Antarctic (excluding South Georgia). Discovery Repts., 10:1-208. , 1936. Foraminifera. Part IV. Additional records from the Weddell Sea sector from material obtained by the S.Y. 'Scotia'. Discovery Repts., 13:1-76.

Echols, R. J., 1971. Distribution of foraminifera in sediments of the Scotia Sea Area, Antarctic Waters. Antarctic Res. Ser., Am. Geophys. Union, 15:93-168.

Ericson, D. B., and Wollin, G., 1968. Pleistocene climates and chronology in deep-sea sediments. Science, 162:1227-1234.

Flint, J. M., 1899. Recent foraminifera. A descriptive catalogue of specimens dredged by the U.S. fish commission steamer "Albatross". Smithson Inst. U.S. Natl. Mus. Rept., 1897:251-349.

Göes, A., 1896. The Foraminifera, in Reports on the dredging operations off the West coast of Central America to the Galapagos, to the West coast of Mexico, and in the Gulf of California, in charge of Alexander Agassiz, carried on the U.S. Fish Commission Steamer “Albatross," during 1891. Bull. Mus. Comp. Zool., (1):1-103.

Herb, R., 1971. Distribution of recent benthonic foraminifera in the Drake Passage. In Llano, G. A., and Wallen, I. E. (Eds.), Biology of the Antarctic Seas IV. Antarctic Research Series, Vol. 17. Washington D. C. (Am. Geophys. Union). 
Heron-Allen, E., and Earland, A., 1911. On the recent and fossil Foraminifera of the shore-sands of Selsey Bill, Sussex, 7. Supplement (Addenda et Corrigenda). J. R. Microsc. Soc., 1911:298-343. 1932. Foraminifera. Part I. The ice-free area of the Falkland Islands and adjacent seas. Discovery Repts., 4:29-460.

Jones T. R., and Parker, W. K., 1860. On the rhizopodal fauna of the Mediterranean, compared with that of the Italian and some other Tertiary deposits. Q. J. Geol. Soc, London, 16:292-307.

Karrer, F., 1866. Über das Auftreten von Foraminiferen in den älteren Schichten des Wiener Sandsteins, K. Akad. Wiss. Wien, Sitzungsber., 52(1):492-497.

Kohl, B., and Shipboard Scientists, 1985. Biostratigraphy and sedimentation rates of the Mississippi Fan. In Bouma, A. H., Normark, W. R., and Barnes, N. E., Submarine Fans and Related Turbidite Systems: New York (Springer-Verlag), pp. 267-273.

LeRoy, D. O., and Hodgkinson, K. A., 1975. Benthonic foraminifera and some pteropoda from a deep-water dredge sample, northern Gulf of Mexico. Micropaleontology, 21(4):420-447.

Loeblich, A. R., Tappan, H., 1964. Foraminifera. In Moore, R. C. (Ed.), Treatise on Invertebrate Paleontology, Pt. C, Protista 2. New York (Geol. Soc. Am.) Vol. 1, pp. 55-510a, text, figs. 34-399, Vol. 2, pp. 511-900, text, figs. 400-653.

Milam, R. W., and Anderson, J. B., 1981. Distribution and ecology of recent benthic foraminifera of the Adelie-George $\mathrm{V}$ continental shelf and slope, Antarctica. Mar. Micropaleontol., 6:297-325.

Norman, A. M., 1878. On the genus Haliphysema with a description of several forms apparently allied to it. Ann. Mag. Nat. Hist., Ser. $5,1: 265-284$.

D'Orbigny, A., 1839. Foraminifères. In de la Sagra, R. (Ed.), Histoire physique, Politique et Naturelle de l'Ile de Cuba: Paris (A. Bertrand).

1846. Foraminiferes Fossiles du Basin Tertiaire de Vienne (Autriche). Paris (Gide et Compe).

Parker, F. L., 1954. Distribution of the foraminifera in the northeastern Gulf of Mexico. Bull Mus. Comp. Zool., 111(10):453-588. pl. 1-13.
Parker, W. K., and Jones, T. R., 1865. On some Foraminifera from the North Atlantic and Arctic Ocean, including Davis Straits and Baffin's Bay. Philos. Trans. R. Soc. London, 155:325-441.

Phleger, F. B., and Parker, F. L., 1951. Ecology of foraminifera, northwest Gulf of Mexico. Mem. Geol. Soc. Am., 46: Pt. 1, Foraminifera distribution, pp. 1-88; Pt. 2, Foraminifera species, pp. 1-164.

Poag, W. C., 1981. Ecologic Atlas of Benthic Foraminifera of the Gulf of Mexico: Stroudsburg, Pa. (Hutchinson \& Ross).

, in press. Distribution and ecology of deep-water benthic foraminifera in the Gulf of Mexico. Palaeoceanog., Palaeoclimatol., Palaeoecol.

Robertson, D., 1891. Trochammina Bradyi, n.n. Ann. Mag. Nat. Hist., London, (Ser. 6), 7:388.

Sars, G. O., 1872. Undersqgelser over Hardangerfjordens Fauna. Vidensk.-Selsk. Christiana, Forhandl., 1871:246-255.

Schulze, F. E., 1875. Zoologische Ergebnisse der Nordseefahrt vom 21. Juli bis 9. September, 1872, I. Rhizopoden. Komm. Wiss. Untersuchung Deutscher Meere in Kiel, Jahresbericht, Berlin, 2-3: pp. 99-114.

Sidner, B. R., and McKee, T. T., 1976. Geochemical controls on vertical distribution of iron-rich agglutinated foraminifers in late Quaternary continental slope sediments from northwest Gulf of Mexico. Am. Assos. Pet. Geol. Bull., 60:722.

Silvestri, A., 1904. Ricerche strutturali su alcune forme dei Trubi di Bonfornello (Palermo). Accad. Pont. Nuovi. Lincei, Mem., 22: 235-276.

Wright, T. J., 1891. Report on the foraminifera obtained off the southwest of Ireland during the cruise of the "Flying Falcon," 1888 Proc. R. Irish Acad., (Ser. 3) 1(4):460-502.

Date of Initial Receipt: 20 November 1984 Date of Acceptance: 30 June 1985 


\section{J. SCHROEDER}
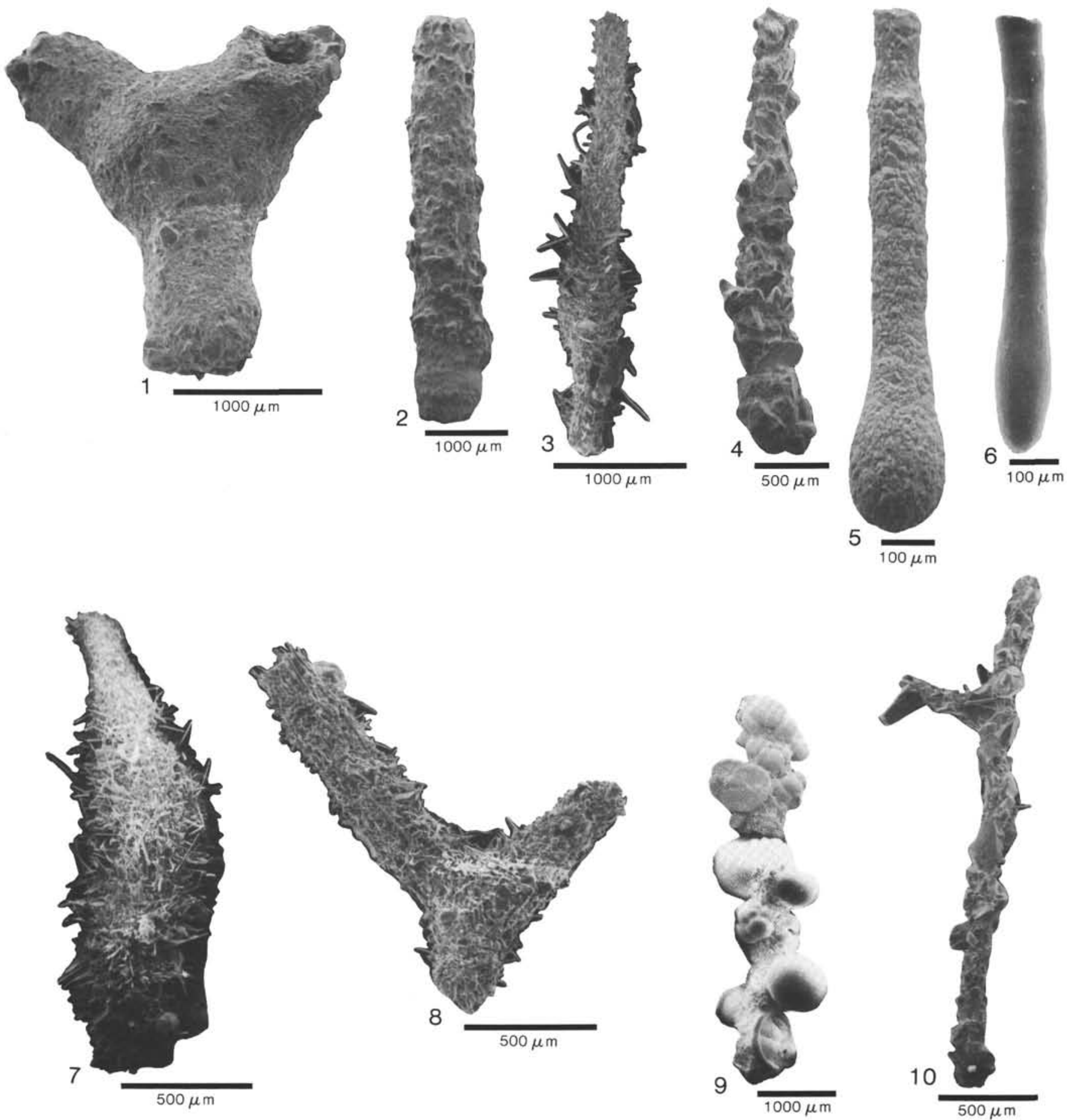

Plate 1. 1. Rhabdammina abyssorum Carpenter, Core 620-1, top, 2. Rhabdammina discreta Brady, Core 620-1, top. 3. Rhabdammina linearis Brady, Section 622-1-1, top. 4. Hyperammina sp., Section 622-1-1, top. 5. Hyperammina elongata, Section 619A-1-1, top. 6. Hyperammina laevigata, Section 619A-1-1, top. 7. Technitella legumen, Section 622-1-1, top. 8. Saccorhiza ramosa (Brady), Section 620-1-1, top, the initial globular chamber is broken. 9. Rhizammina indivisa Brady, Section 622-1-1, top. 10. Rhizammina algaeformis Brady, Section 622-1-1, top. 

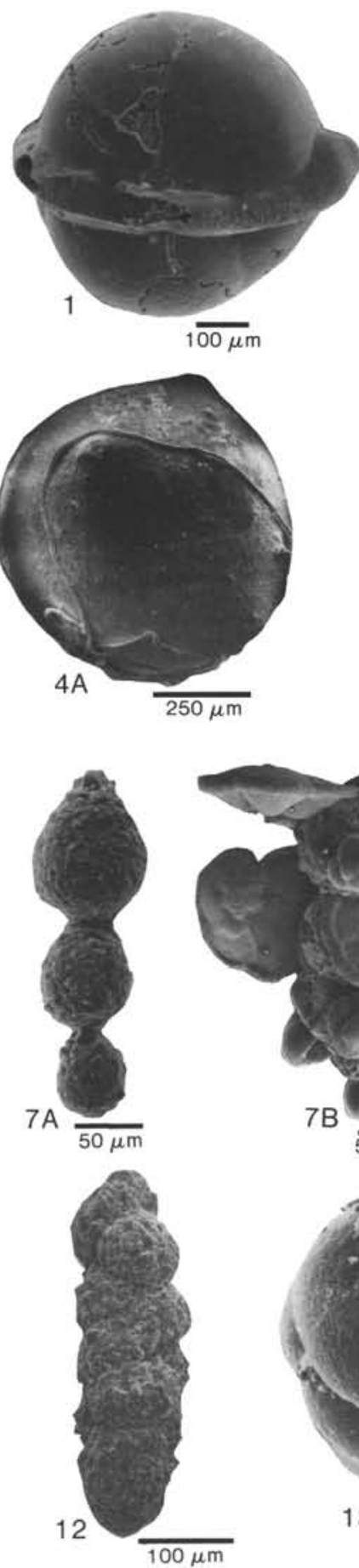
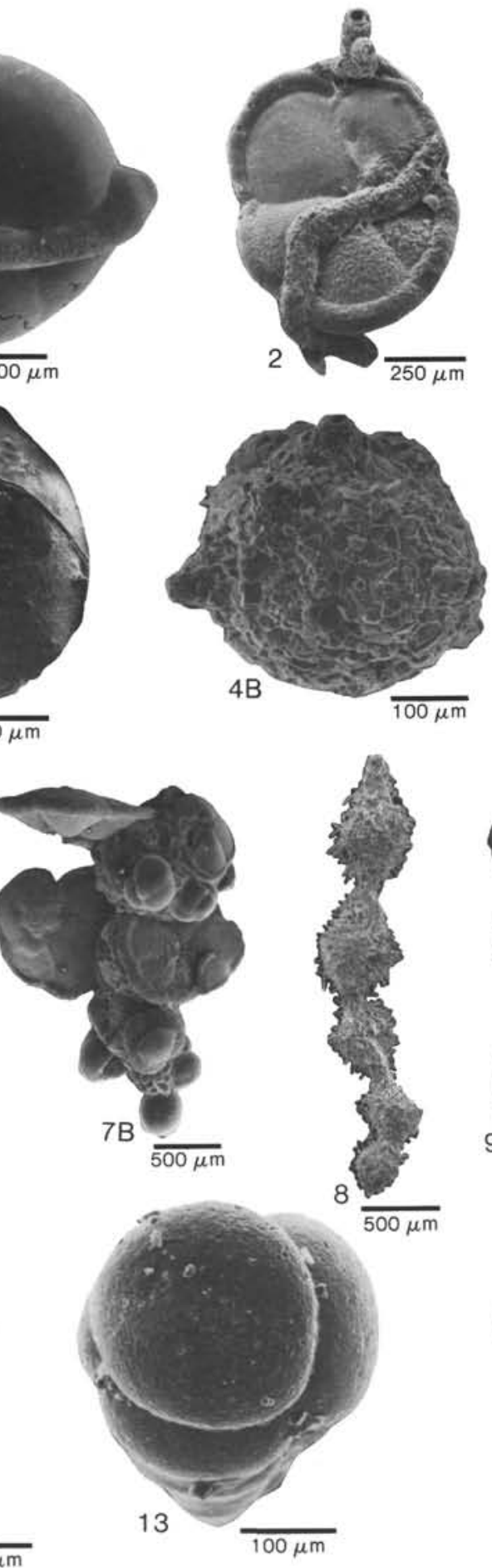
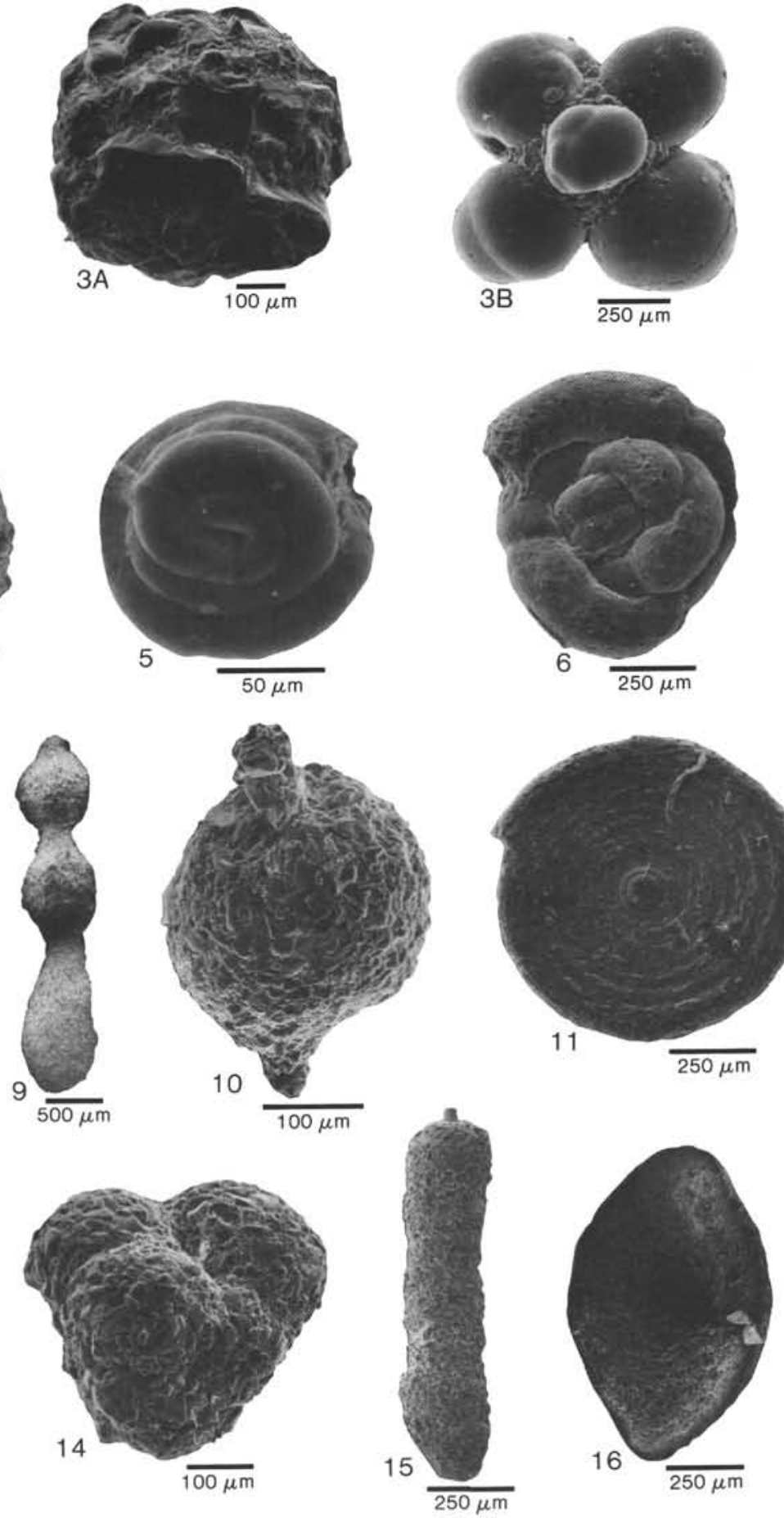

Plate 2. 1. Ammolagena clavata (Jones and Parker), Section 620-1-1, top. Test is attached to a planktonic foraminiferal test. 2. Tolypammina vagans (Brady), Section 620-1-1, top. Test is attached to a planktonic foraminiferal test. 3A, B. Psammosphaera fusca Schulze, (A) Section 620-1-1, top, (B) Section 621-1-1, top. Test agglutinated large shells of planktonic foraminifers. 4A, B. Thurammina papillata Brady, (A) Section 622-1-1, top, (B) Section 619A-1-1, top. 5. Glomospira charoides (Jones and Parker), Section 619A-1-1, top. 6. Trochamminoides proteus (Karrer), Section 619A-1-1, top. 7a, b. Reophax pilulifer Brady, (A) Section 619A-1-1, top. (B) Section 622-1-1, top. 8. Reophax guttifer Brady, Section 622-1-1, top. 9. Hormosina carpenteri Brady, Section 620-1-1, top. 10. Reophax distans Brady, Section 619A-1-1, top. 11. Ammodiscus incertus (d'Orbigny), Section 620-1-1, top. 12. Karreriella apicularis (Cushman), Section 619A-1-1, top. 13. Eggerella bradyi (Cushman), Section 619A-1-1, top. 14. Eggerella propinqua (Brady), Section 621-1-1, top. 15. Martinottiella occidentalis (Cushman), Section 619A-1-1, top. 16. Sigmoilopsis schlumbergeri (Silvestri), Section 620-1-1, top. 

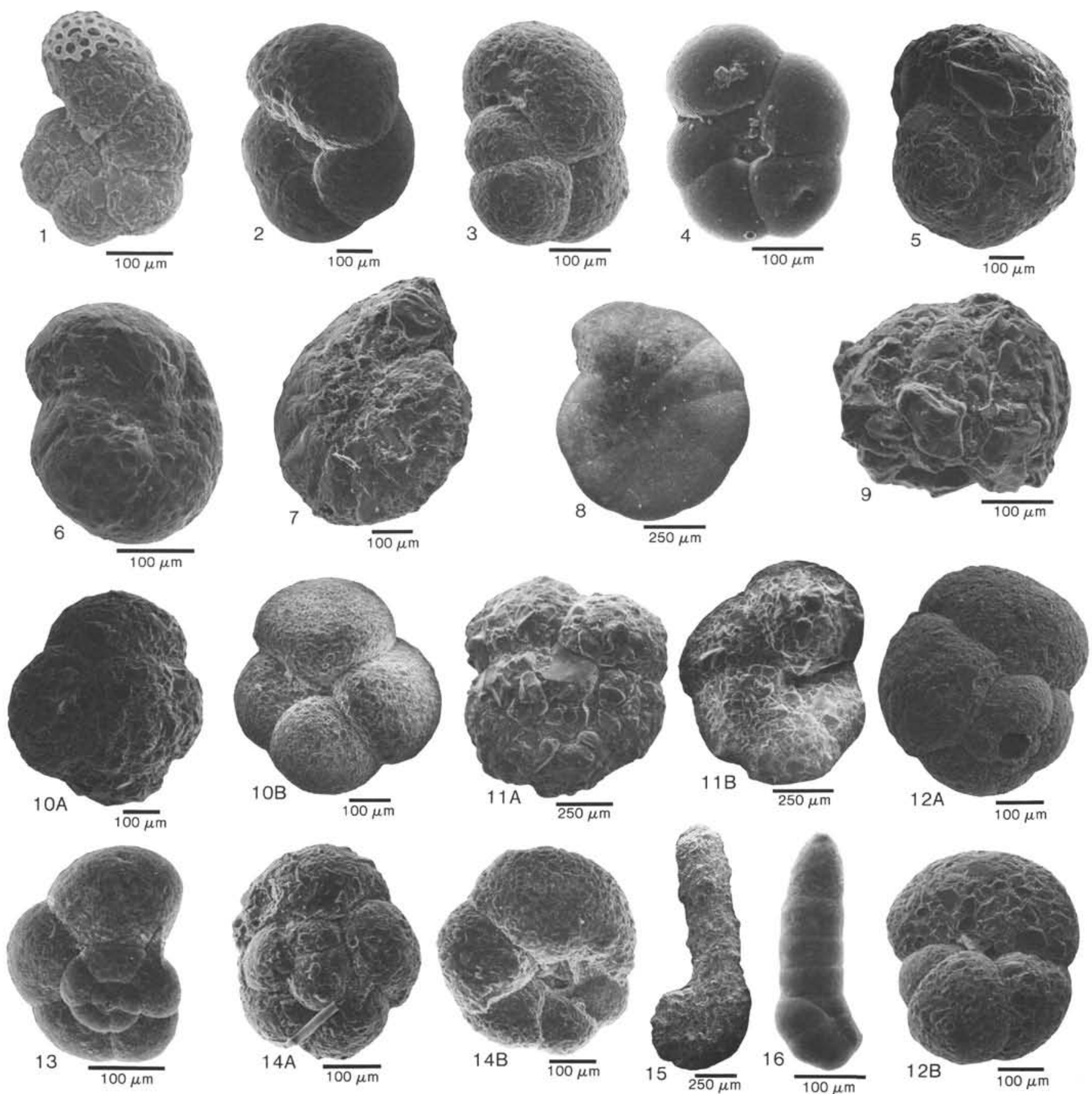

Plate 3. 1. Haplophragmoides canariensis (d'Orbigny), Section 619A-1-1, top. 2. Cribrostomoides nitidus (Goës), Section 620-1-1, top. 3. Haplophragmoides shaeriloculus Cushman, Section 619A-1-1, top. 4. Haplophragmoides bradyi (Robertson), Section 621-1-1, top. 5. Cribrostomoides subglobosus (Sars), Core 620-1, top. 6. Recurvoides scitulus (Brady), Section 619A-1-1, top. 7. Cyclammina pusilla Brady, Section 624-1-1, top. 8. Cyclammina trullissata (Brady), Core 620-1, top. 9. Adercotryma glomerata (Brady), Section 620-1-1, top. 10A, B. Trochammina globigeriniformis (Parker and Jones), (A) spiral side, (B) umbilical side, Section 619A-1-1, top. 11A, B. Trochammina soldanii Earland, (A), spiral side, (B) umbilical side, Section 619-1-1, top. 12A, B. Trochammina globulosa Cushman,(A) spiral side, (B) umbilical side, Section 619A-1-1, top. 13. Trochammina glabra Heron-Allen and Earland, Section 619A-1-1, top. 14A, B. Trochammina rotaliformis HeronAllen and Earland, (A) spiral side (B) umbilical side, Section 619A-1-1, top. 15. Ammobaculites agglutinans (d'Orbigny), Section 620-1-1, top. 16. Ammobaculites agglutinans var. filiformis Earland, Section 619A-1-1, top. 